Kapata Arkeologi, 12(2), 137-146

ISSN (cetak): 1858-4101

ISSN (elektronik): 2503-0876

http://kapata-arkeologi.kemdikbud.go.id

\title{
TEKNOLOGI TEMPA LOGAM PADA MASA LALU DI DAERAH ALIRAN SUNGAI PAWAN, KALIMANTAN BARAT (sebuah pendekatan etnoarkeologi)
}

\section{Metal Forging Technology in the Past in the Pawan Watershed, West Kalimantan \\ (An Ethnoarchaeology Approach)}

\author{
Ida Bagus Putu Prajna Yogi \\ Balai Arkeologi Kalimantan Selatan - Indonesia \\ Jl. Gotong Royong II. RT. 06/ RW.03, Banjarbaru, Kalimantan Selatan \\ idabagus.prajna@kemdikbud.go.id
}
Naskah diterima: 10/09/2016; direvisi: 23/11 - 29/11/2016; disetujui: 15/12/2016
Publikasi ejurnal: 30/12/2016

\begin{abstract}
Archaeological evidence of metal artifacts found in the area Pawan Watershed in the number of inviting attention to be investigated, that is how the process of technology in the past. The existence of the craftsmen of wrought metal along the watershed area Pawan certainly was not a coincidence. There might be a relationship between the presence of artifacts with traditional metal forging which is still survive until recently. Ethnoarchaeological approach that has been undertaken is expected to give an idea to reconstructs the metal forging technology in the past on Pawan Watershed; to understand the cultural continuity that still exists today in the area. Metal forging technology using the "ububan" the which is still used today in several locations in Indonesia, as well as in Pawan Watershed. This study concluded that the technology workmanship metal artifacts in the past has the similarity from the technological progress that has continued until recently.
\end{abstract}

Keywords: Artifacts Metals, Pawan River, Ethnoarchaeology, Metals Technology

\begin{abstract}
Abstrak
Bukti arkeologi berupa artefak logam yang ditemukan di daerah aliran Sungai Pawan dalam jumlah yang cukup banyak mengundang perhatian untuk diteliti, yaitu bagaimana teknologi dan proses pengerjaannya pada masa lalu. Keberadaan pengrajin logam tempa di sepanjang daerah aliran Sungai Pawan tentu bukan suatu kebetulan, mungkin ada hubungan antara kehadiran artefak dengan teknologi tempa logam tradisional yang masih bertahan saat ini. Pendekatan etnoarkeologi dilakukan dalam penelitian ini diharapkan dapat memberikan gambaran untuk merekonstruksi teknologi tempa logam di masa lalu di daerah aliran Sungai Pawan untuk melihat dan belajar tentang kelangsungan budaya yang masih ada saat ini di lokasi tersebut. Teknologi penempaan logam dengan menggunakan "ububan" yang masih digunakan saat ini di beberapa lokasi di Indonesia dan di daerah aliran Sungai Pawan. Penelitian ini menyimpulkan bahwa teknologi artefak pengerjaan logam di masa lalu tidak jauh berbeda dari kemajuan teknologi yang masih berlangsung hingga saat ini.
\end{abstract}

Kata kunci: Artefak Logam, Sungai Pawan, Ethnoarkeologi, Teknologi Logam

\section{PEDAHULUAN}

Dalam pemenuhan kebutuhan manusia, teknologi merupakan intrumen penting dalam menunjang kebutuhan manusia. Manusia telah menerapkan teknologi sejak keberadaannya di muka bumi ini. Manusia merupakan satusatunya mahluk yang berhasil mengembangkan emosi dan intelegensianya sampai pada taraf yang sangat tinggi. Dengan kemampuannya, manusia mampu menciptakan teknologi berbagi alat dan teknologi untuk melakukan abstraksi secara efisien, apa yang dibutuhkan bagi kehidupannya dengan memanfaatkan sumber 
daya yang ada di sekelilingnya (Sahari 2008, 9$10)$.

Dalam kehidupan manusia paling tidak ada empat jenis bahan utama yang pada umumnya dipakai oleh manusia untuk pembuatan alat, yaitu tanah, batu, logam, dan kayu atau bambu. Tiga jenis bahan yang pertama adalah jenis bahan yang seringkali masih bertahan menghadapi perjalanan waktu sehingga dapat ditemukan para peneliti, ketiga jenis bahan tersebut memiliki proses yang lebih rumit dibandingkan dengan yang lain, terutama bahan logam. Itulah sebabnya teknologi logam pada umumnya, merupakan indikator perkembangan peradaban tinggi yang telah dicapai manusia (Haryono, 2001: 1).

Teknologi logam termasuk sebagai extractive technology, yaitu teknologi yang dalam prosesnya mengurangi, dari bahan dasar teknologi logam pada umumnya, merupakan indikator perkembangan peradaban tinggi yang telah dicapai manusia, kemudian direduksi sampai menjadi bentuk artefak. Diawali dari tahap pengadaan bahan mentah dengan cara penambangan bijih logam, kemudian dilanjutkan dengan pengolahan untuk mendapatkan bahan siap pakai sampai kemudian menjadi artefak. Proses yang rumit itulah yang kemudian melahirkan pengetahuan metalurgi. Dalam sejarah peradaban manusia, penggunaan dan pemanfaatan logam merupakan suatu revolusi teknologi, dalam pengertian bahwa telah terjadi perubahan teknologi dari teknologi batu atau tanah ke teknologi logam (Haryono, 2008: 50).

Sungai Pawan terletak di Propinsi Kalimantan Barat, sungai ini bermuara di Kabupaten Ketapang dan mengaliri beberapa wilayah di Kalimantan Barat. Sungai Pawan memiliki beberapa anak sungai dan hulunya berasal dari beberapa tempat yaitu di daerah pegunungan Scawaner di kabupaten Sintang, di kabupaten Skadau dan beberapa berasal dari pegunungan di Kalimantan Tengah. Di sepanjang aliaran Sungai Pawan dan anak sungianya, terdapat beberapa desa yang letaknya tepat berada di tepi Sungai Pawan dari muara hingga ke hulu sungai.

Sungai ini memiliki lebar rata-rata badan sungai di daerah muara sebesar $500 \mathrm{M}$. Sungai ini dapat dilayarai oleh kapal berukuran sedang hingga sampai ke daerah hulu. Di sepanjang aliran Sungai ini banyak terdapat desa-desa yang masyarakatnya banyak bergantung pada aliran
Sungai Pawan, sebagai saran transportasi dan untuk melakukan aktifitas lainnya.

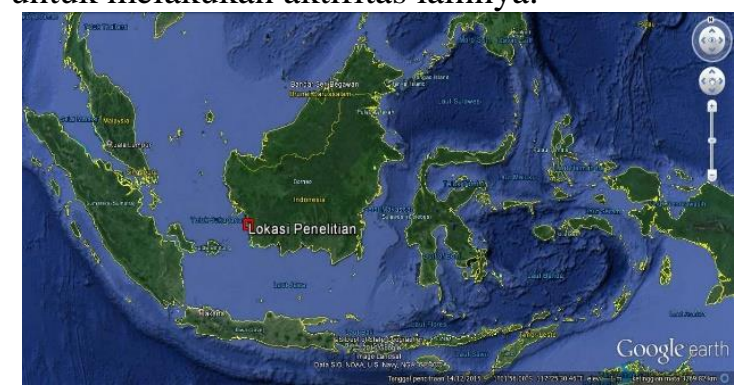

Gambar 1. Citra Satelit 1: Lokasi Penelitian (Sumber: Google Earth yang dimodifikasi oleh IBP. Prajna Yogi, 2016)

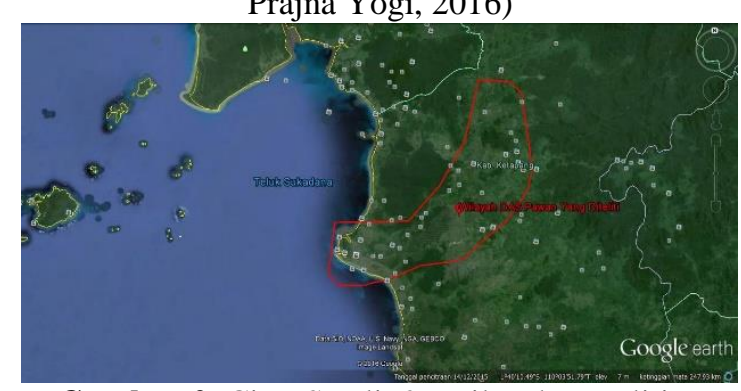

Gambar 2. Citra Satelit 2: Wilayah Penelitian (Sumber: Google Earth yang dimodifikasi oleh IBP. Prajna Yogi, 2016)

Dalam beberapa penelitian ekplorasi arkeologi, banyak ditemukan data arkeologi berupa artefak logam di daerah Aliran Sungai Pawan, selain itu secara tidak sengaja juga dalam proses survei tersebut pada setiap permukiman yang hingga kini masih dihuni oleh masyarakat, hampir selalu ditemui para pandai besi yang menggunakan teknologi tempa tradisonal. Berdasarkan fenomena tersebut maka dilakukan penelitian yang lebih spesifik mengenai teknologi pembuatan artefak besi tersebut pada masa lalu dengan tujuan untuk mengetahui dan rekontruksi teknologi tempa logam tradisonal pada masa lalu di Daerah Aliran Sungai Pawan.

Teknologi tempa logam, merupakan salah satu bagian dari kegiatan untuk memenuhi kebutuhan ekonomi. Untuk memenuhi kebutuhan, maka manusia membutuhkan kegiatan-kegiatan yang menyangkut atas kebutuhan, kegiatan ini disebut juga sebagai kegiatan ekonomi. Sebagaimana yang didefinisikan oleh ahli antropologi ekonomi yang dikemukakan oleh Karl Polanyi bahwa ekonomi adalah upaya yang dilakukan manusia untuk memenuhi kebutuhan hidup di tengah lingkungan alam dan lingkungan sosialnya (Polanyi dalam Sairin, 2002, 16-17). 
Ilmu arkeologi berusaha untuk mengetahui aspek perilaku manusia masa lampau melalui jejak-jejak yang ditinggalkan, yang berupa benda-benda, baik yang berbentuk alat maupun bukan alat. Perilaku manusia yang telah mengahasilkan tinggalan-tinnggalan arkeologis mencakup 3 hal, yaitu buat, pakai dan buang (Sharer and Ashmore, 1977) yang merupakan proses awal tebentuknya data arkeologi.

Pembuatan artefak logam memiliki tingkat kesulitan paling tinggi dan prosesnya lebih rumit dibandingkan dengan bahan yang lainnya yang kemudian melahirkan pengetahuan metalurgi. Karena kerumitan itulah maka tidak mengherankan apabila pengetahuan metalurgi kemudian menjadi tolok ukur bagi munculnya peradaban (Childe, 1950).

Para Pandai logam dikatakan sebagai fulltime specialist atas dasar dua pertimbangan. Pertama bahwa pengerjaan logam memerlukan perhatian yang penuh. Pertimbangan kedua, dalam sejarah para pandai logam bangsa Eropa pada awalnya mereka adalah itinerant yang tidak sempat atau tidak dapat memproduksi makanannya sendiri: "Metalworkers thus had to make their living "on the road", providing their services to many chiefs and villages"(Wailles, 1996:5).

Isu tentang budaya logam berpengaruh dalam hal difusi kebudayaan, khususnya unsur teknologi. Di satu pihak adalah kelompok yang berpendapat bahwa hanya ada satu pusat munculnya pengetahuan metalurgi yang kemudian menyebar ke beberapa temapat melalui difusi, sedangkan pihak lain berpendapat bahwa ada beberapa pusat munculnya budaya logam sebagai local development. Isu tersebut sangat mewarnai permasalahan kebudayaan logam di Asia Tenggara (Bayard 1979. ).

\section{METODE}

Data dalam penelitian ini adalah bersifat kualitatif, dimana pendekatan yang digunakan adalah pendekatan etnoarkeologi. Oswalt (1974) menyatakan bahwa etnoarkeologi adalah penelitian yang dilakukan menggunakan perspektif arkeologi tentang budaya material, berdasarkan informasi lisan tentang artefak yang diperoleh dari orang yang berhubungan langsung dengan artefak tersebut atau keturunan langsung dari mereka (Ameer, 1998: 18). Studi etnoarkeologi memiliki tujuan untuk memberikan gambaran rekonstruksi tentang masa lalu melalui tinggalan-tinggalan yang masih dijumpai dan dipergunakan hingga saat ini oleh sekelompok masyakarakat atau suku. Penggunaan data etnografi sebagai bahan analogi untuk mengungkap kembali tatacara kehidupan masa lampau biasanya mempunyai kedudukan sebagai interpretasi (Tanudirdjo, 1987 : 24).

Data diperoleh melalui observasi lapangan, survei, dan wawancara mendalam sebagai upaya untuk menggali data etnografi yang ada saat ini sehingga diharapkan dapat digunakan sebagai pendukung dalam proses rekontruksi mengenai teknologi pembuatan peralatan logam besi di Daerah Aliaran Sungai Pawan pada masa lalu. Selain itu studi pustaka digunakan sebagai data sekunder dan pelengakap dalam tulisan ini.

\section{HASIL DAN PEMBAHASAN \\ Temuan Artefak Logam di DAS Pawan}

Dalam kegiatan penelitian ekplorasi arkeologi yang kami lakukan di Daerah Aliran Sungai Pawan pada tahun 2012, 2013 dan tahun 2015 kami menemukan cukup banyak artefak logam dibeberapa titik di sepanjang aliran Sungai Pawan dan anak sungainya. Artefak logam tersebut beberapa ditemukan masyarakat di sekitar permukiman mereka, di kebun ketika bercocok tanam, dan ada pula yang ditemukan mereka di dasar sungai ketika menjala ikan. Jumlah temuannyapun tidak sedikit, Pak Yos (64 Tahun) mengungkapkan, bahwa sekitar 30 tahun yang lalu ketika beliau menjala ikan di sungai di sekitar Desa Kenyabur di Hulu Sungai Pawan, menemukan parang pendek yang belum selesai dibuat (belum ada sisi tajaman) dengan jumlah yang cukup banyak diikat dengan rotan. Selain itu beliau juga sangat sering menemukan benda logam seperti kacip (alat pembelah pinang) dan beliung besi di ladang sekitar permukiman (Yogi, 2013, 2015).

Di Desa Sengkuang tepat di sekitar temuan Lingga, ketika kami melakukan penelitian pada tahun 2013 menemukan pahat besi berukuran kecil pada kedalaman sekitar 10 $\mathrm{cm}$ dari permukaan tanah (Foto 2). Pahat tersebut tajam dibagian muka, memiliki bagian yang seharusnya masuk kedalam handle yang kemungkinan terbuat dari kayu. Ada beberapa bentuk serampang (tombak ikan) yang ditemukan di daerah Aliran Sungai Pawan, mulai 
dari yang bermata satu hingga tiga dengan berbagai macam ukuran. Menurut keterangan beberapa narasumber di lapangan dahulu di Sungai Pawan banyak terdapat Ikan dengan ukuran besar, bahkan jenis ikan tapah dapat mencapai panjang dua hingga tiga meter, maka sangat mungkin ditemukan serampang dengan ukuran yang besar pula.

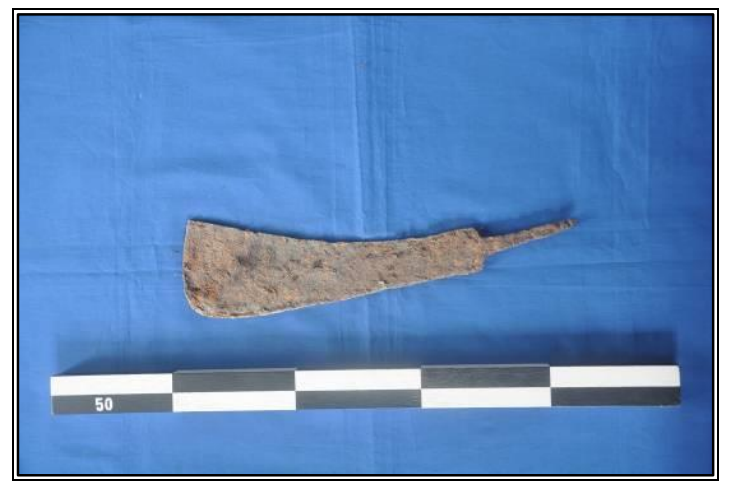

Gambar 3. Parang pendek unfinishing yang ditemukan di dasar Sungai Pawan (Sumber: Difoto IBP Prajna Yogi, 2012)

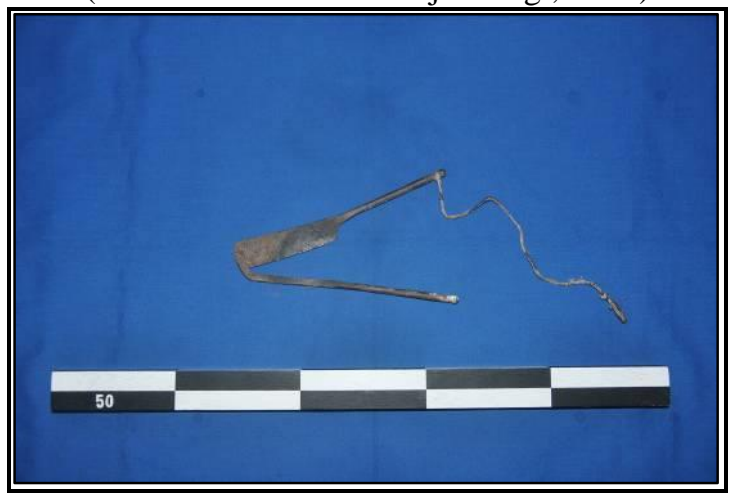

Gambar 4. Kacip pembelah pinang (Sumber: Difoto IBP Prajna Yogi, 2012)

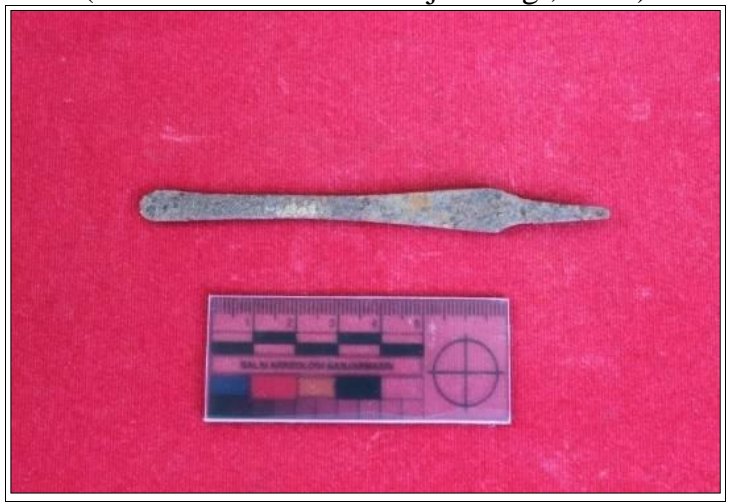

Gambar 5. Pahat besi yang ditemukann disekitar temuan Lingga

(Sumber: Difoto oleh IBP Prajna Yogi, 2012)

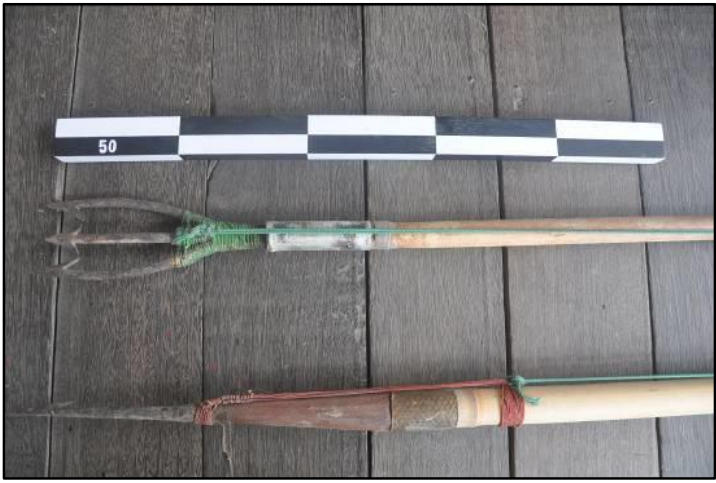

Gambar 6. Serampang tiga dan serampang satu (tombak ikan)

(Sumber: Difoto oleh IBP Prajna Yogi, 2012)

\section{Teknologi dan Proses Pembuatan Benda Logam Yang Masih Berlangsung Di Sungai Pawan}

Saat ini hampir di setiap desa yang berada di Daerah Aliran Sungai Pawan terdapat pandai besi yang masih memproduksi berbagai peralatan logam besi. Mereka melakukan penempaan logam besi tersebut menggunakan teknologi pemanasan yang disebut "puput" (istilah lokal) dan lebih dikenal di Jawa dengan istilah ububan (Foto 3 dan 4). Ububan atau puput ini adalah sebuah alat penghasil udara yang dihasilkan dari dua tabung yang dipompa oleh satu orang pekerja. Tabung tersebut terbuat dari pipa paralon berdiameter 5 inci dan dimasuki klep yang berfungsi sebagai penekan udara keluar bekerja seperti sebuah piston kendaraan bermotor. Dahulu tabung puput ini terbuat dari batang kayu belian/besi/ulin yang dilubangi tengahnya dan klepnya terbuat dari kumpulan bulu burung Ruai (Kuau) yang mereka peroleh di hutan. Sedangkan handle untuk pegangan dalam menggerakan klep terbuat dari rotan. Udara yang keluar dari kedua tabung tersebut kemudian dialirkan menggunakan dua pipa kecil untuk disemburkan perapian yang sedang menyala. Perapian yang menyala tersebut merupakan arang kayu tertentu yang memiliki daya bakar cukup lama. Biasanya kayu yang digunakan adalah kayu-kayu keras yang diperoleh di hutan, sehingga pembakaran dapat maksimal.

Berdasarkan hasil wawancara dengan beberapa padai besi, mereka menyatakan bahwa teknologi tersebut sudah berlangsung sejak dahulu kala dan diturunkan secara turuntemurun oleh para orang tua meraka. Rata-rata para pandai besi yang terdapat di daerah Aliran 
Sungai Pawan ini merupakan anak-anak yang melanjutkan usaha orang tua mereka yang sejak dahulu kala berprofesi sebagai pandi besi. Untuk membuktikan hasi kerja dan kualitas produksinya maka kami mencoba memesan sebuah mandau. Dalam waktu sekitar satu minggu dihasilkan mandau dengan kualitas yang sangat baik dengan pengerjaan yang halus serta presisi yang sangat baik.

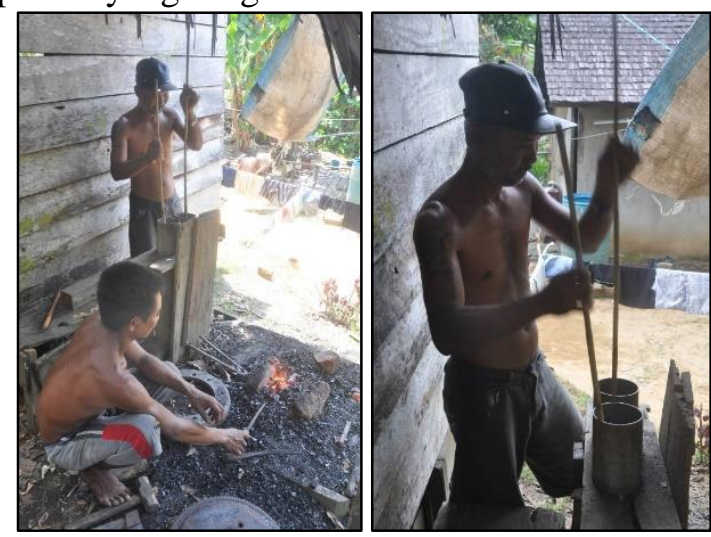

Gambar 7. Aktifitas pandai besi di Hulu Sungai Pawan

(Sumber: Difoto IBP Prajna Yogi, 2012)

Saat ini benda-benda yang dihasilkan oleh para pengerajin tempa logam di Daerah Aliran Sungai Pawan ini berupa peralaan pertanian, peralatan berburu dan beberapa perlatan rumah tangga lainnya. Para pandai besi ini juga masih dapat membuat bebrpa benda yang ditemukan dalam penelitain arkeologi di Daerah Aliran Sungai Pawan, seperti parang, serampang, tombak dan pahat yang terbuat dari besi.

Selain puput sebagai pengasil udara dalam proses tempa besi, peralatan lain yang digunakan yaitu: Tang jepit untuk menjepit besi dalam keadaan panas, palu besi dengan berbagai ukuran, landasan pukul yang terbuat dari besi, dan baskom air atau bak air untuk mendinginkan besi yang sudah selesai ditempa.

Mereka menyebut profesi mereka ini sebagai Pande, sama seperti sebutan bagi pandai besi yang ada di Jawa saat ini. Istilah apande wsi menunjukkan bahwa ia adalah tukang pande yang khusus atau ahli membuat barang-barang dari besi. Barang-barang tersebut mungkin sekali adalah alat pertanian dan senjata (Kusen et.al., 1993: 253-254). Pengerjaan barangbarang dari logam merupakan penciptaan kekuasaan, sebab alat-alat dari logam pertamatama diperlukan untuk perang, baru sesudahnya untuk pertanian. Logam, khususnya besi, dipandang mengandung kekuatan dan keteguhan (Reid, 2011: 120).
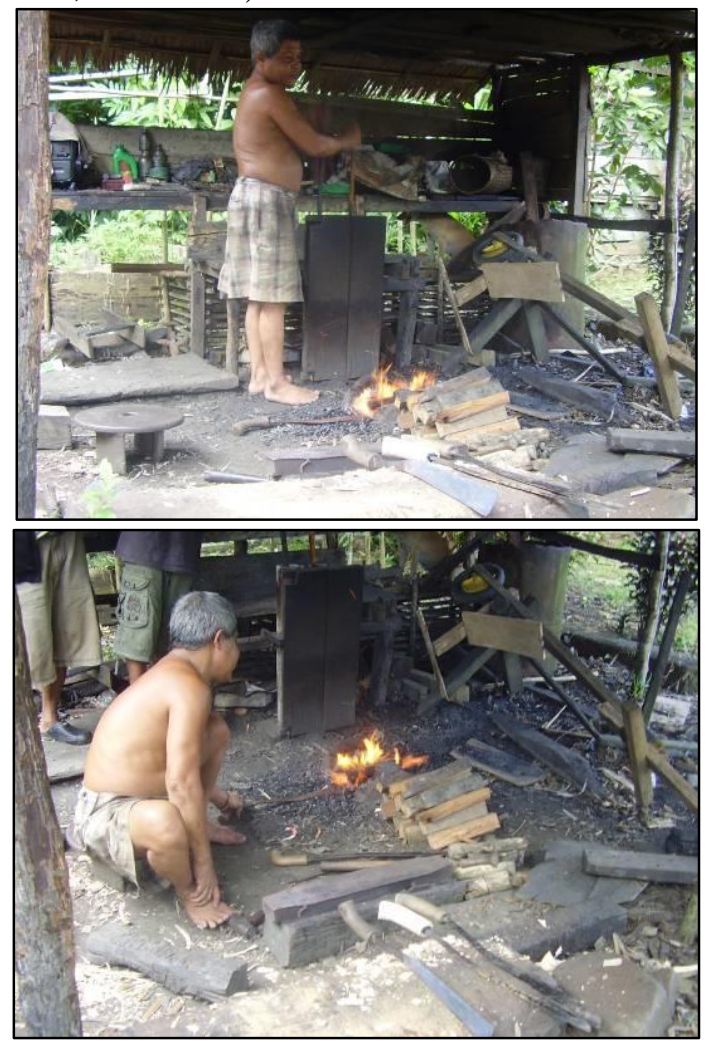

Gambar 8. Aktivitas pandai besi di daerah Hilir Sungai Pawan

(Sumber: Difoto IBP Prajna Yogi, 2012)

Proses Pembuatan Benda Logam di Darah Aliran Sungai Pawan saat ini melalui beberapa tahapan. (1) mencari bahan baku logam yang akan dipanaskan dan membuat model benda yang akan dibentuk, (2) menyiapkan bara api (3) membakar logam sampai merah membara sehingga mudah dibentuk (4) menempa sesuai model yang diinginkan (untuk tahapan 3 dan 4 dapat dilakukan berulang ulang hingga menjadi bentuk yang diinginkan) (5) mencelup kedalam air agar suhu panasnya berkurang (6) jika sudah menjadi bentuk yang diinginkan kemudian dikikir /digrenda supaya rapi (7) untuk membuat senjata tajam atau peralatan tajam lainnya diperlukan tahapan pengasahan.

Dalam sebuah bengkel pandai besi sebenarnya ada empat pembagian kerja untuk memperoleh hasil pekerjaan yang maksimal dengan waktu yang singkat. Empat pembagian kerja tersebut ialah:

1. Pande

Pande atau ada yang menyebut Empu atau guru pandai besi. Dia mengatur produksi 
setiap peralatan yang dibuat. Empu memegang besi yang akan dibentuk sekaligus mengatur bagian mana yang harus ditempa agar menjadi bentuk alat seperti yang di inginkan. Penempaan besi ini tergantung arahan dari empu. Bisa dikatakan empu ini merupakan desainer dalam pande besi.

2. Panjak

Panjak merupakan pengayun palu. Ada dua atau tiga orang panjak dalam satu area kerja pande besi. Selama bekerja, panjak mengambil tempat di belakang paron (landasan tempa), menghadap empu. Ketika empu meletakkan batang besi merah panas di atas paron (landasan tempa), panjak mengayunkan palunya di atas kepala, menghentakkannya ke bawah dengan pukulan keras, mengubah bentuk batang logam itu dan sekaligus meningkatkan kepadatannya. Jika ada dua atau tiga panjak, mereka menempa secara bergantian, menciptakan nada dua atau tiga ketukan yang terdengar seperti musik.

3. Tukang Puput

Tukang puput adalah orang yang bertugas memompa angin agar arang membara. Tukang ubub duduk di atas panggung pompa dan menurunkan batang ubub dengan irama dua ketukannya sendiri. Ububan (pompa) berupa dua buah tabung silindris yang dipasang berjejeran. Dua tabung ini di dalamnya diberi klep yang bisa digerakkan ke atas dan ke bawah seperti gerak pompa ban. Pada bagian lain dari tabung ububan ini terdapat pipa pendek. Pipa pendek ini ditanam di dalam tanah dalam kedalaman sekitar 10-15 cm. Pada bagian ujung pipa ini diletakkan (ditimbunkan) arang membara. Nyala api bara ini bisa diperpanas atau diperbesar dengan "tiupan" angin dari ububan. Kadang ububan juga dapat digantikan dengan pompa tangan.

4. Tukang Kikir

Tukang kikir mengasah dan/atau menggerinda bagian pinggiran alat untuk membuatnya tajam. Dia bisa jadi mengerjakan tugas finishing lainnya, seperti menggosok permukaan alat dengan ampelas, atau memoles bagian luarnya dengan lapisan pelindung anti karat. Tukang kikir duduk terpisah dari pekerja lainnya, di sebuah sudut area kerja atau di tempat yang teduh di bawah lis atap persis di luar area kerja. Sembari bekerja, dia terkadang duduk bersila, dan terkadang duduk dengan satu kaki menjulur menahan rak kecil tempat bersandarnya alat yang sedang dikerjakan.

\section{Cerita Rakyat Mengenai Teknologi Tempa Logam di DAS Pawan}

Beberapa narasumber yang ditemui dilapangan memberikan gambaran mengenai siapa yang mengajarkan teknologi pengerjaan logam di daerah aliran Sungai Pawan pada masa lalu. Petrus Singa Bansa (45 tahun) yang juga saat ini merupakan Raja dari Kerajaan Hulu Aik di Hulu Sungai Pawan mengkisahkan bahwa "Ilmu menempa logam di daerah aliran Sungai pawan ini diajarkan oleh tokoh yang bernama Sengkumang, tokoh ini dikisahkan datang dari tanah Jawa pada masa kerajaan Majapahit bersama sekor anjing kesayangannya dan mengajarkan cara menempa logam dan membuat berbagai peralatan dari logam. Tokoh ini digambarkan tinggal disekitar di sekitar Desa Sengkuang saat ini di sekitar telaga pancur keramat. Di telaga pancur keramat sendiri saat ini terdapat tinggalan berupa lingga batu tanpa yoni. Masyarakat sekitar di hulu Sungai Pawan menyebut batu tersebut sebagai Butuh Sengkumang (kemaluan si Sengkumang) dan masyarakat tidak mengetahui kalo itu merupakan lingga.

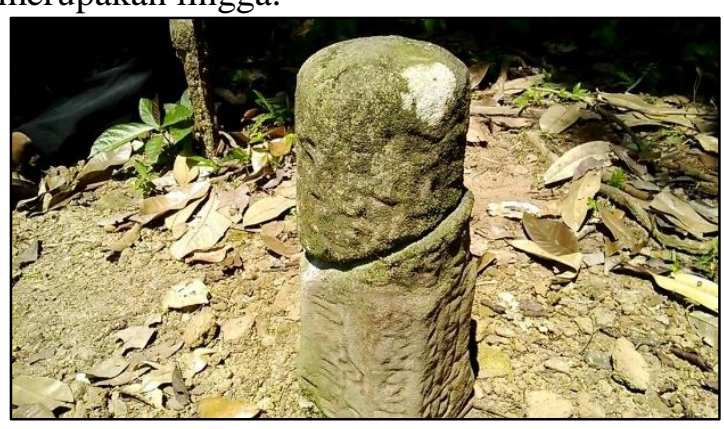

Gambar 9. Lingga dengan Inskripsi ditemukan di Desa Sengkumang di Daerah Aliran Sungai Pawan (Sumber: Difoto oleh IBP Prajna Yogi, 2013)

Dalam penelitian di tahun 2013, kami berusaha membersihkan lingga tersebut dari lumut yang tumbuh memenuhi seluruh permukaan, setelah lingga tersebut dibersihkan ternyata terdapat Inskripsi di bagian Visnu Bagha nya. Setelah kami berkonsultasi dengan beberapa epigraf di Indonesia, analisis awal menyebutkan inskripsi tersebut bertuliskan aksara palawa muda diperkirakan berasal dari abad ke $13 \mathrm{M}$ hingga awal abad ke $16 \mathrm{M}$. 
Namun, hingga saat ini inskripsi tersebut belum terbaca.

Berdasarkan cerita rakyat yang berkembang di masyarakat tersebut dan didukung oleh data material, menunjukan bahwa ada sebuah difusi budaya teknologi logam yang berasal dari luar. Kemungkinan budaya tersebut dibawa oleh pihak luar dan kemudian ditiru atau sengaja diajarkan pada masyarakat lokal. Kebudayaan yang baru tersebut kemudian diturunkan secara turun temurun melalui proses belajar.

\section{Ketersediaan Sumber Bahan Logam di DAS Pawan}

Pertimbangan ekonomis berhubungan dengan keberadaan sumber bahan. Di dalam teori invensi dikatakan bahwa invensi teknologi di suatu wilayah budaya akan terjadi apabila terpenuhi beberapa syarat, yaitu kepandaian masyarakat (genius), kebutuhan terhadap benda itu sendiri (needs), kesempatan untuk mencipta (opportunity), dan tersedianya sumber bahan (resources). Ketersediaan sumber bahan belum menjamin terciptanya suatu karya apabila masyarakatnya belum memiliki kemampuan. Demikian pula sebaliknya tidak adanya sumber bahan bukan faktor penghalang terjadinya invensi teknologi karena masyarakat sangat memerlukan kepandaian untuk menghasilkan suatu benda. Oleh karena itu, kalau tuntutan kebutuhan masyarakat akan benda-benda yang terbuat dari logam cukup besar, meskipun di wilayah yang bersangkutan tidak cukup tersedia deposit bijih logam bahan dasar, maka bahan dasar dapat diperoleh melalui kontak dagang. Pada masa klasik, sebagaimana tampak dari berbagai prasasti tercermin adanya kegiatan ekonomi menjual logam sebagai bahan dasar pembuatan artefak-artefak. (Haryono, 2001: 6).

Kekayaan Daerah Aliran Sungai Pawan akan barang tambang, utamanya adalah timah dan besi pada masa lalu juga dibicarakan dalam catatan P.J Veth dari laporan perjalanan beberapa orang Eropa pada masa lalu. Besi, selain ditambang dan diolah oleh orang-orang Dayak di daerah Siduk, juga ditambang di daerah pantai Selatan Muara Sungai pawan, khususnya di kawasan sungai Air Itam dan Jelai. Besi ini yang dikenal dengan sebutan baja dari Matan (Kesultanan Islam pada masa itu), banyak dikirim ke Pontianak. Mengenai soal apakah orang-orang Dayak di Matan juga membuat senjata, seperti halnya dalam Kerajaan Banjar, terutama di daerah Negara (sekalipun terdapat kekurangan bahan) yang mencapai tingkat kualitas yang tinggi; saya tidak bisa menuturkan; namun hal ini mungkin saja. di wlayah Kapuas, orang-orang Dayak yang tidak menambang besi dan meleburnya (dan hanya dibeberapa tempat saja hal ini ada), ternyata mampu mengolah dan mengerjakan besi menjadi tombak, parang, dan peralatan lain, dengan menggunakan besi yang berasal dari Inggris atau Swedia, yang mereka peroleh melalui raja-raja mereka (Veth, 2012:136-137).

Saat ini para Pandai besi di Daerah Aliran Sungai pawan memperoleh bahan baku untuk membuat benda logam terutama yang berbahan besi dengan cara mendaur uang besi bekas yang sudah tidak digunakan lagi seperti fungsi awanya, seperti: besi bekas per mobil, cakram kendaraan, bekas mata pisau pemotong kayu, ataau berbagai benda besi lainnya. Beberapa pengerajin menyatakan dahulu berdasarkan kisah para pendahulu mereka, bahwa ada bahan besi yang bisa ditemukan disekitar Daerah Aliran Sungai Pawan bagian hulu, namun saat ini sudah sangat sulit ditemui lagi material besi yang ada di alam. Wujud besi alam tersebut bongkahan besi menyerupai batu.

\section{Teknologi Tempa Logam Menggunakan Ububan (Puput) di Nusantara}

Nusantara telah mempunyai kemampuan mengolah berbagai benda kebutuhan menggunakan bahan bermaterial logam sebelum adanya pengaruh budaya dari luar. Secara hipotesis Dr. J.L.A. Brandes pernah menyatakan bahwa jauh sebelum mendapat pengaruh dari kebudayaan India, bangsa Indonesia telah memiliki pengetahuan dan kemampuan dalam bidang metalurgi. Pengetahuan metalurgi merupakan salah satu dari 10 unsur kebudayaan yang telah dimiliki bangsa Indonesia, yaitu: wayang, gamelan, ilmu irama puisi, membatik, mengerjakan logam, sistem mata uang, ilmu pelayaran, astronomi, penanaman padi, dan birokrasi pemerintahan (Timbul Haryono, 2008: $60)$.

Logam besi adalah jenis logam yang pengerjaannya termasuk teknik tempa panas (hot working). Teknologi logam Jawa kuno pada abad VIII tidak lagi dalam tahap eksperimental, tetapi sudah mencapai tahap yang matang, yang disebabkan oleh faktor kebutuhan yang lebih 
banyak terhadap benda-benda yang digunakan dalam sistem budaya pada saat itu. Penentuan dan pemilihan logam secara sengaja, didasarkan pada pertimbangan-pertimbangan tertentu, seperti faktor teknis, faktor simbolis, faktor estetis dan mungkin juga faktor ekonomis. Pertimbangan-pertimbangan tersebut akan disesuaikan dengan pertimbangan yang menyangkut segi-segi teknik perwujudan suatu benda. Dalam sejarah teknologi terbukti bahwa jauh sebelum manusia menemukan unsur-unsur suatu material, mula-mula yang menarik perhatian manusia adalah daya tarik estetisnya. Kemudian setelah itu dimanfaatkan untuk tujuan artistik, magis dan religius (Haryono, 2001: 57).

Di Jawa sendiri sumber dari relief memang tidak begitu banyak yang memberikan gambaran tentang kelompok penggarap industri ini. Namun ada satu adegan dalam salah satu relief Candi Sukuh di lereng Gunung Lawu yang menggambarkan suatu kelompok industri khususnya pande besi. Bahkan pada relief tersebut terlihat pula gambaran tentang alat-alat yang digunakan serta alat-alat yang dihasilkan (Subroto dan Pinardi, 1993: 208-209).

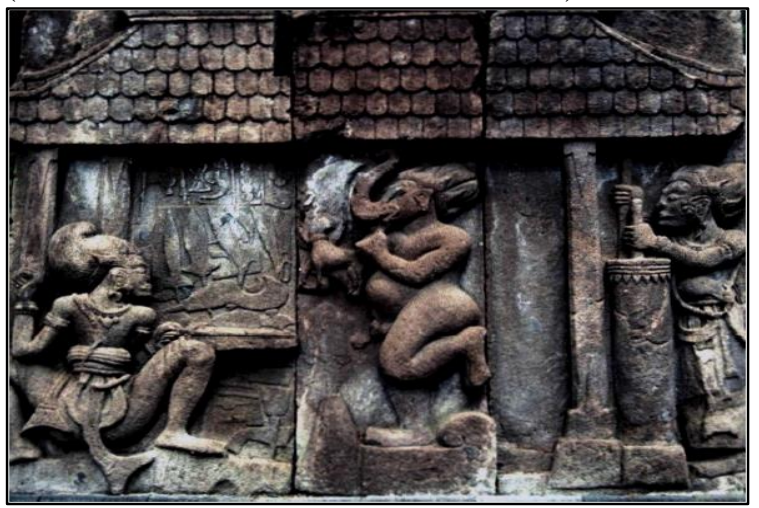

(Gambar 10. Relief di Candi Sukuh, menggambarkan pandai besi yang menggunakan Ububan)

(Sumber: Subroto, 1993)

Dari gambaran yang ada, dapat diketahui alat-alat yang digunakan serta posisi masingmasing tokoh dalam relief tersebut sehingga dapat diketahui cara kerja pande besi pada saat itu. Berdasarkan gambar relief tersebut, untuk pekerjaan pande besi, paling tidak diperlukan dua pekerja (1 orang pengubub dan 1 orang pande). Pada salah satu bangunan di Candi Sukuh digambarkan dua tokoh saling berhadapan, tokoh yang pertama berada di sebelah kanan (selatan) digambarkan berdiri menghadapi sebuah ububan (alat penghembus udara), dengan kedua tangannya memegangi kedua tongkat ububan. Tokoh yang ke 2 berada di sebelah kiri (utara) dalam posisi duduk jongkok dengan kedua kaki terbuka, sedangkan tangan kiri memegang sebuah tongkat panjang yang disodorkan ke arah tempat keluarnya api dari ububan. Di depan tokoh tersebut terdapat bermacam-macam alat atau barang yang dihasilkan. Di antara kedua tokoh tersebut terdapat relief yang menggambarkan seorang manusia berkepala gajah, dengan posisi berdiri di atas satu kaki membelakangi tokoh yang memegang tongkat ububan. Tangan kanan memegang seekor binatang, sedangkan tangan kiri memegang ekor binatang tersebut. Sebagai latar belakang gambar binatang tersebut, tampak adanya gambar seperti lidah api. Kalau kedua tokoh yang pertama digambarkan lengkap dengan pakaian dan perhiasan, tetapi tidak demikian halnya dengan tokoh manusia berkepala gajah, hanya ada surban di kepalanya. Dengan adanya relief pandai besi pada suatu candi, menunjukkan bahwa golongan pekerja ini mempunyai peranan dan kedudukan penting dalam menunjang kehidupan suatu kerajaan (Subroto dan Pinardi, 1993: 213).

Alat-alat yang tampak di relief Candi Sukuh adalah ububan, supit / sapit, palu, paron, tatah dan kikir. Sapit adalah alat untuk menjepit bahan logam yang akan di tempa, baik dalam perapian maupun sedang ditempa. Palu adalah alat untuk memukul bahan tempaan agar menjadi tipis dan padat. Paron adalah landasan benda tempaan. Di Candi Sukuh, paron diletakkan bersama-sama dengan atau sekelompok dengan palu. Jenis alat lain yang terdapat di Candi Sukuh adalah tatah (Subroto dan Pinardi, 1993: 213).

Lain halnya di Tidore, dalam bahasa lokal (Tidore) alat penghasil hembusan angin disebut dengan nama dua dua. Hembusan angin merupakan peralatan penting yang pakai dalam pekerja pandai besi yang berfungsi memompa angin ke tungku. Hembusan angin terbuat dari Pohon Linggua yang dilubangi bagian tengahnya atau dapat mengunakan pipa. Hembusan angin ini kemudian disambung bambu/pipa kecil pada bagian bawahnya, dan sambungan tersebut mengarah ke tungku. Dan untuk menghasilkan angin, hembusan tersebut dipompa dengan mengunakan dua batang rotan atau bambu pada dua hembusan tersebut kemudian ujung 
rotan/bambu di ikat dengan bulu ayam sesuai dengan ukuran lubang hembusan. Bahan bakar yang di gunakan yaitu arang dari kulit kenari. Bahan bakar tersebut masih mudah didapatkan yakni mereka mengambilnya di kebun atau di hutan. Arang dari kulit kenari lebih tebal dapat dipakai membakar besi selama dua atau tiga produksi (Dukomalamo, 2012: 6-7).

\section{KESIMPULAN}

Banyaknya temuan artefak logam di Daerah Aliran Sungai Pawan dan keberadaan pandai besi di setiap desa di sepanjang aliran Sungai Pawan dan anak sungainya hingga saat ini bukan suatu hal yang kebetulan, namun sebuah kebersinambungan budaya yang terus berlanjut sejak masa lalu. Dalam merekontruksi teknologi pembuatan artefak logam yang ditemukan di beberapa tempat di Daerah Aliran Sungai Pawan menggunakan pendekatan etnoarkeologi sangat memungkinkan untuk dilakuakan.

Berdasarkan hasil observasi dan wawancara mendalam di lapangan, diperoleh suatu gambaran mengenai teknologi tempa logam yang diturunkan secara turun temurun oleh nenek moyang mereka. Kemungkinan teknologi yang digunakan pada masa lalu tidak jauh berbeda dengan teknologi tradisional yang masih berlangsung hingga saat ini. Artefak logam yang ditemukan di beberapa situs yang terdapat di daerah aliran Sungai Pawan dalam beberapa penelitian arkeologi kemungkinan besar dapat diproduksi secara lokal oleh pengerajin-pengerajin yang diperkirakan mulai ada di Daerah Aliran Sungai Pawan tersebut sejak abad ke-14 seiring dengan masuknya pengaruh luar di wilayah tersebut berdasarkan data arkeologi yang menunjukan masa tersebut.

Teknologi pemanasan material logam agar mudah dibentuk menggunakan alat yang dikenal dengan nama ububan di Jawa dan puput di Daerah Aliran Sungai Pawan, menunjukkan sebuah pengaruh yang dibawa seiring dengan perluasan kekuasaan dari pusat kerajaan besar yang berkembang di Jawa pada masa itu berdasarkan artefak pembanding lainnya yang ditemukan. Data arkeologi seperti yang digambarkan pada relief di candi Sukuh (Abad 15) menunjukan aktifitas tempa logam yang menggunakan peralatan dan proses yang sama dengan apa yang saat ini masih berlangsung di Daerah Aliaran Sungai Pawan.
Namun, mengenai pengaruh atau difusi budaya yang terjadi, sebaiknya dilakukan penelitian yang lebih spesifik agar intepretasi awal tersebut dapat terbukti dan data-datanya semakin lengkap. Kesimpulan diatas dapat digunakan sebagai hipotesa dalam penelitian mengenai difusi budaya yang terjadi di Daerah Aliran Sungai Pawan pada masa lalu.

\section{Ucapan Terima Kasih}

Artikel ini merupakan salah satu hasil dari penelitian eksplorasi arkeologi Daerah Aliran Sungai Pawan di Kalimantan Barat. Artikel dari hasil penelitian ini tidak akan terwujud tanpa bantuan banyak pihak.Penulis mengucapkan terimakasih kepada semua pihak yang telah banyak membantu sehingga terlaksananya beberapa penelitian arkeologi yang berlagsung di Daerah Aliran Sungai Pawan, yaitu; seluruh staf Balai Arkeologi Banjarmasin, khususnya saudara Imam Hindarto dan Eko Herwanto yang selalu memberikan masukan kepada penulis selama melakukan penelitian arkeologi di Daerah Aliran Sungai pawan, Kalimantan Barat.

Tidak lupa pula penulis ucapakan terimakasih kepada seluruh sahabat di Kabupaten Ketapang yang telah banyak membantu penulis dalam berbagai kegiatan penelitian Arkeologi di daerah Sungai Pawan, yaitu; Pak Muryani, Pak Yudo, Pak Yos di menyumbung, almarhum Pak Montel (ketua Lembaga Adat Dayak Kerio), Pak Kutal, Raja Hulu Aik (Petrus Singa Bangsa), Gusti Kamboja (Pangeran Kerajaan Matan) dan semua pihak yang tidak dapat penulis sebutkan satu persatu.

$$
* * * * *
$$

\section{DAFTAR PUSTAKA}

Ameer, Naseem. K.Thimma Reddy. (1998). Settlement Archaeology. New Delhi: Reliance Publishing House.

Bayard, Donn T. (1979). "The Chronology of Prehistoric Metallurgy in Northeast Thailand: Silabhumi or Samraddhabhumi? Dalam R.B. Smith and W. Waston (ed.).Early South East Asia. Essays in Archaeology, History, and Historical geography. New York: Oxford.

Dukomalamo, Syahril. (2012). Pandai Besi di Kelurahan Toloa Kecamatan Tidore Selatan Kota Tidore Kepulauan. Jurnal Holistik Tahun V No 10 A. Manado: Fakultas Ilmu Solial dan Politik Universitas Sam Ratulangi. 
Haryono, Timbul, dkk. (2000). Koleksi Emas Museum Sonobudoyo, Yogyakarta: Proyek Pembinaan Permuseuman DIY.

Haryono, Timbul. (2001). Analisis Metalurgi: Peranannya Dalam Eksplanasi Arkeologi. Humaniora Volume XIII, No. 1. Yogyakarta: Fakultas Ilmu Budaya Universitas Gadjah Mada.

Haryono, Timbul. (2001). Logam dan Peradaban Manusia. Yogyakarta: Philosophy Press.

Haryono, Timbul. (2008). Seni Pertunjukan dan Seni Rupa dalam Perspektif Arkeologi Seni, Surakarta: ISI Press Solo.

Kusen et.al. (1993). "Seni Majapahit" [The Art of Majapahit], article in 700 Tahun Majapahit. Suatu Bunga Rampai [700 Years of Majapahit. An Anthology], Surabaya: Dinas Pariwisata, pp.235- 268.

Reid, Anthony. (2011). Asia Tenggara dalam Kurun Niaga 1450-1680 Jilid 1: Tanah di Bawah Angin, Jakarta: Yayasan Pustaka Obor Indonesia.

Tanudirdjo, Daud Aris. (1987). Laporan Penelitian Penerapan Etnoarkeologi di Indonesia. Yogyakarta: Fakultas Sastra Universitas Gadjah Mada Yogyakarta.

Sahari Besari, M. (2008). Teknologi Di Nusantara: 40 Abad Hambatan Inovasi. Salemba Teknika. Jakarta.

Sairin, Sjafri. (2002). Pengantar Antropologi Ekonomi. Pustaka Pelajar. Yogyakarta.

Sharer, Robert J. dan Wendy Ashmore. (1975). Fundmentals of Archaeology. California: The Banjamin/ Cumming Pubishing Company, Inc.

Subroto dan Slamet Pinardi. (1993). "Sektor Industri pada Masa Majapahit", dalam Sartono Kartodirdjo dkk (ed), 700 Tahun Majapahit (1293-1993): Suatu Bunga Rampai, Surabaya, Dinas Pariwisata Daerah Jawa Timur.

Veth, P.J. (2012). Borneo Bagian Barat Geografis, Statistis, Historis." Dialih bahasakan olah Yeri,P,OFM.Cap. Buku Asli: Borneo's Westerafdeeling Geographisch, Statistisch, Historisch" Zaltbommel, Joh Noman en Zoon (1856). Pontianak: Institut Dayakologi.

Wailes, Bernard. (1996). "V. Gordon Childe and the Relations of Production". Bernard Wailies (ed). Craft Specialization and Social evolution: In Memory of V. Gordon Childe.

Wertime, Th. A. (1964). “Man's First Encounters with Metallurfy" in Science 146: 1257-1267.

Yogi, IBP. Prajna. (2013). Eksplorasi DAS Pawan Bagian Hulu dan Anak Sungainya di Kalimantan Barat "Laporan Penelitian Arkeologi:" Banjarbaru: Balai Arkeologi Banjarmasin.

Yogi, IBP. Prajna. (2015). Survei Eksplorasi Arkeologi di Daerah Aliran Sungai Pawan
Bagian Hilir dan Pesisir Kabupaten Ketapang "Laporan Penelitian Arkeologi:" Banjarbaru: Balai Arkeologi Banjarmasin.

\author{
Data Informan Wawancara \\ Nama : Pak Yos \\ Usia : 64 Tahun \\ Pekerjaan : Pensiunan Kepala Sekolah dan \\ Dewan Adat Dayak Kerio
}

$\begin{array}{ll}\begin{array}{l}\text { Nama } \\ \text { Bansa) }\end{array} & \text { : Raja Hulu Aik ( Petrus Singa } \\ \begin{array}{l}\text { Usia } \\ \text { Pekerjaan } \\ \text { (Lingga) }\end{array} & \begin{array}{l}\text { : } 45 \text { Tahun } \\ \text { Nama }\end{array} \\ \begin{array}{l}\text { Usia } \\ \text { Pekerjaan }\end{array} & \text { : Pak Yena Tahan Pancur Kerama } \\ \text { Nama } & \text { : Hendrikus Igang } \\ \text { Usia } & : \text { 49 Tahun } \\ \text { Pekerjaan } & : \text { Pandai Besi di Desa } \\ \text { Menyumbung } & \end{array}$

